\title{
www.mychronicdisease.org: - Naar de patiënt activerende en ondersteunende chronische zorg
}

Citation for published version (APA):

Spreeuwenberg, C. (2008). www.mychronicdisease.org: - Naar de patiënt activerende en ondersteunende chronische zorg -: Afscheidsrede door Prof. dr. C. Spreeuwenberg. (1 ed.) Universiteit Maastricht. https://doi.org/10.26481/spe.20080613cs

Document status and date:

Published: 13/06/2008

DOI:

10.26481/spe.20080613cs

Document Version:

Publisher's PDF, also known as Version of record

\section{Please check the document version of this publication:}

- A submitted manuscript is the version of the article upon submission and before peer-review. There can be important differences between the submitted version and the official published version of record.

People interested in the research are advised to contact the author for the final version of the publication, or visit the DOI to the publisher's website.

- The final author version and the galley proof are versions of the publication after peer review.

- The final published version features the final layout of the paper including the volume, issue and page numbers.

Link to publication

\footnotetext{
General rights rights.

- You may freely distribute the URL identifying the publication in the public portal. please follow below link for the End User Agreement:

www.umlib.nl/taverne-license

Take down policy

If you believe that this document breaches copyright please contact us at:

repository@maastrichtuniversity.nl

providing details and we will investigate your claim.
}

Copyright and moral rights for the publications made accessible in the public portal are retained by the authors and/or other copyright owners and it is a condition of accessing publications that users recognise and abide by the legal requirements associated with these

- Users may download and print one copy of any publication from the public portal for the purpose of private study or research.

- You may not further distribute the material or use it for any profit-making activity or commercial gain

If the publication is distributed under the terms of Article $25 \mathrm{fa}$ of the Dutch Copyright Act, indicated by the "Taverne" license above, 
wWw.mychronicdisease.org:

- naar de patiënt activerende en ondersteunende chronische zorg - 


\section{Colofon}

Ontwerp en print: Océ Business Services, Maastricht

ISBN: 978-90-5681-326-0

NUR: 870

Alle rechten voorbehouden. Niets uit deze uitgave mag worden verveelvoudigd, opgeslagen in een geautomatiseerd gegevensbestand of openbaar gemaakt worden, zonder voorafgaande schriftelijke toestemming van de auteur of uitgever. 


\title{
www.mychronicdisease.org: \\ - naar de patiënt activerende en \\ ondersteunende chronische zorg -
}

\author{
Afscheidsrede \\ Op vrijdag 13 juni 2008 \\ uitgesproken in La Bonbonnière, Maastricht \\ door
}

Prof. dr. C. Spreeuwenberg

Hoogleraar 'Eerste- en Tweedelijns zorg voor chronische zieke patiënten' in de Faculty of Health, Medicine and Life Sciences

\section{Maastricht University}





\section{Mijnheer de rector magnificus, dames en heren,}

Alvorens met dit afscheidscollege te beginnen, wil ik $U$ zeggen dat ik het zeer op prijs stel dat $U$ allen hier in zo' $n$ groten getale aanwezig bent. Het is goed om de hoogtepunten in het leven te markeren en daar is deze dag er één van. $U$ draagt daar toe bij en daarom vind ik het fijn dat $\mathrm{U}$ er bent.

\section{Rode draden naar opvattingen over chronische zorg}

Ik wil kort schetsen welke rode draden er te zien zijn in mijn werkzaam leven die hebben geleid tot mijn zienswijze nu over de zorg aan chronische zieken.

Gisteren was het 45 jaar geleden dat ik in dienst ging en dit al snel leidde tot een functie als officier gevechtsleiding bij de Koninklijke Luchtmacht. Daar heb ik geleerd wat samenwerken inhoudt en dat niet de rang maar de actuele functie de doorslag geeft. In de lucht kon een sergeant als leider van een formatie de functionele meerdere zijn van een vlieger die kapitein was. Die ervaring is terug te vinden in mijn denken over de verhouding tussen arts en verpleegkundige.

Als kandidaat-assistent kwam ik er achter dat biologisch onderzoek mij zeer interesseerde, maar dat ik het grootste genoegen zou ontlenen aan het werken met of voor patiënten.

$\mathrm{Na}$ het artsexamen koos ik voor de interne geneeskunde. Hierin boeide me het stellen van een goede diagnose, aanvankelijk alleen in klinische zin, maar later steeds meer in de eigenlijke betekenis van diagnose: het doorhebben wat er aan de hand is. Uit deze tijd vloeit voort dat ik zeer hecht aan de klinische competentie van de huisarts en aan samenwerking tussen de huisarts en de specialist. Dit laatste is in mijn leeropdracht aan deze universiteit terug te zien.

In die ziekenhuisperiode viel het me op dat een goede dokter weliswaar wil weten wat er aan de hand is, maar dat daarover met patiënten nauwelijks werd gecommuniceerd en al helemaal niet als mensen hun eindigheid concreet onder ogen moesten gaan zien. De hulpverlening aan mensen die gaan sterven, heeft substantieel deel van mijn werk uitgemaakt.

Als huisarts kreeg ik de gelegenheid om mij verder in samenwerking te verdiepen. Met mijn hier aanwezige collegae van destijds in zowel Emmen als Nieuwegein werd een groepspraktijk opgericht en vormden wij met andere professionals een eerstelijnsteam. In die jaren zeventig 
hadden sommigen binnen de eerste lijn het merkwaardige idee dat samenwerkenden elkaars vrienden moest zijn en dat alle informatie en werkzaamheden konden worden gedeeld en uitgewisseld. Ons team vormde object van studie voor de hoogleraar Groffen waaruit de theorie over 'subdisciplinaire samenwerking' is ontstaan.' Samenwerken verrijkt pas als daarbinnen specifieke deskundigheid een plaats heeft en functioneert alleen als verantwoordelijkheid, aansprakelijkheid en taakverdeling goed zijn geregeld. Deze kenmerken ziet $u$ later terug in de definiëring van transmurale zorg.

$\mathrm{Na}$ de jaren van het handwerk kreeg ik de kans me te verdiepen en te verbreden. Allereerst academisch in Utrecht en aan de VU. Maar ook beroepsinhoudelijk door mijn betrokkenheid bij het opstellen van het eerste basistakenpakket van de huisarts en de formulering in 1984 van het baanbrekende standpunt van de KNMG over euthanasie. ${ }^{23}$

Het hoofdredacteurschap van Medisch Contact bood me de gelegenheid om de inhoudelijke gezondheidszorg en het gezondheidsbeleid met elkaar in verband te brengen.

Deze ervaringen hebben mijn visie op de wijze waarop de gezondheidszorg om moet gaan met mensen met een chronische ziekte gevormd en daar wil ik $U$ nu iets over vertellen.

\section{Chronische zieken}

De aandacht voor chronisch zieken en ziekten dateert pas van de jaren tachtig. De overheid formuleerde in 1990 voor het eerst beleid op dit terrein met als direct gevolg de oprichting van Nationale Commissie Chronisch Zieken. ${ }^{4}$ De nieuwe aandacht werd ingegeven door de toename van het aantal chronisch zieken en de specifieke aard van het lijden hieraan.

Tabel 1

Verwachte stijging aantal chronisch zieken

\begin{tabular}{|lcc|}
\hline $\begin{array}{c}1990-2010 \\
\text { oratie 19945 } \\
\text { (prevalentie) }\end{array}$ & $\begin{array}{c}2005-2025 \\
\text { afscheid 2008 } 6 \\
\text { (absoluut aantal) }\end{array}$ \\
\hline beroerte & $35 \%$ & $44 \%$ \\
\hline COPD & $23 \%$ & $38 \%$ \\
\hline dementie & $39 \%$ & $38 \%$ \\
\hline diabetes mellitus & $54 \%$ & $32 \%$ \\
\hline hartfalen & & $47 \%$ \\
\hline
\end{tabular}


De omvang neemt toe doordat we ouder worden, er relatief minder kinderen worden geboren, het succes van medische interventies is toegenomen en onze samenleving allerlei verleidingen kent om nogal ongezond te leven. Sinds de jaren negentig luidt de boodschap steevast dat het aantal chronisch zieken de komende jaren zal toenemen (tabel 1).

Beleidsmakers vragen zich af hoe zij die toename tegen kunnen gaan, zoals blijkt uit een conferentie van ministers van volksgezondheid van de EU hierover deze maand. In een concept dat diende ter voorbereiding werd de stijging als een ramp aangeduid. Dat is overdreven want deze is immers voor een groot deel toe te schrijven aan het beter onder de knie krijgen van infectieziekten, acute hartproblemen en kanker en het terugdringen van het aantal ernstige ongevallen.

Het lijkt me onvermijdelijk te accepteren dat voorlopig meer mensen chronisch ziek worden maar laten we ons wel inspannen om toename die te voorkomen is, tegen te gaan. Een aantal chronische ziekten wordt immers in belangrijke mate bepaald door roken, ongezonde voeding, gebrek aan lichaamsbeweging en - samenhangend hiermee - de sociale klasse. Met het oog hierop zal er serieuzer werk moeten worden gemaakt van gerichte preventie en het bevorderen van gezondheidsgedrag.

Maar in preventie en gedragsverandering zit niet het verschil met acute aandoeningen. Dat verschil betreft de gevolgen. Een chronische ziekte gaat in de regel niet over waardoor iedereen die hierdoor wordt getroffen voor de opgave staat zich op de één of andere wijze aan te passen en de ziekte een plaats te geven in zijn of haar leven. Een chronische ziekte gaat nogal eens gepaard met consequenties op een ander gebied: sociaal door verlies van werk, verlies van inkomsten of beperking van mobiliteit of psychisch door bijvoorbeeld depressie, zoals bij één op de zes patiënten met diabetes het geval is.7 Een chronische ziekte treft niet alleen de betrokkene maar ook zijn of haar primaire omgeving.

\section{Zorgverlening aan chronische zieken}

Helaas is de huidige zorgverlening op deze eisen niet toegesneden want de zorg wordt inhoudelijk niet altijd optimaal gegeven, is vaak lang niet patiëntgericht, is onvoldoende toegankelijk en eenzijdig medisch gericht en er is onvoldoende samenhang en afstemming tussen zorgverleners. Bovendien krijgt de procesmatige kant van de zorgverlening te weinig aandacht. lemand die net ziek is geworden heeft andere vragen dan iemand die hier al een lange tijd mee kampt. 
Toch staat de gezondheidszorg voor de uitdaging het verlenen van zorg te baseren op deze eigen aard van chronische ziekten en de specifieke gevolgen daarvan voor betrokkenen. Deze situatie vereist een breuk met de wijze waarop we tot nu toe de inhoudelijke zorgverlening, de organisatie daarvan en het gezondheidszorgbeleid hebben geregeld. Deze drie facetten moeten afzonderlijk en in hun samenhang worden bezien.

\section{Inhoudelijke zorg}

Inhoudelijk staat het buiten kijf dat chronisch zieken recht hebben op goede, medisch verantwoorde, zorg. Wat dat is en hoe die moet worden geboden, is echter veel minder simpel dan in het geval van een acute gebeurtenis. Bij een infarct staat niet ter discussie wat er moet gebeuren, waar de behandeling plaatsvindt en wie de behandeling zal uitvoeren. Maar in het geval van een chronische aandoening staat dat alles veel minder vast. Een chronische patiënt zal vooral zelf veel moeten doen en de kunst is hoe we de patiënt daarbij kunnen helpen. Hoe kan hij zelf eigenaar van zijn ziekte worden? Natuurlijk, de medische diagnose wordt ook nu door een dokter gesteld, maar het resultaat van de behandeling en begeleiding hangt veel minder van de behandelaar af. Deze is eerder adviseur dan heroïsche doener.

Om dat adviseren goed te kunnen doen, zal er eerst een diagnose moeten worden gesteld in de brede betekenis van doorhebben wat er aan de hand is. De behandelaar moet dus weten hoe de toestand van de betrokkene precies is, wat zijn probleem is en wat hij belangrijk vindt. En dat kan alleen door een gesprek aan te gaan. Daarin blijkt dat een ogenschijnlijk gelijk gezondheidsprobleem door de betrokkenen heel uiteenlopend wordt beleefd en heel verschillende betekenissen voor ze heeft. Naast slachtoffergedrag, schuldgevoelens, uitingen van onvermogen en kampen met de afhankelijkheid, zien we ook veel mensen die er het beste van proberen te maken, zichzelf blijven en zelf bij keuzen betrokken willen zijn. Mensen willen vooral dat er respect is voor hun opvattingen en dat daarmee serieus rekening wordt gehouden. 
In een recent onderzoek van de Samenwerkende Astmapatiënten Verenigingen naar wat patiënten willen, springen er drie aspecten uit: ${ }^{8}$

1. Mensen vragen zich af waarom er zulke grote verschillen in zorgverlening bestaan.

2. Mensen willen grip op hun aandoening krijgen en weten hoe ze er mee om kunnen gaan, dus een zekere mate van controle hebben, en verwachten van de zorgverlening dat die hun de instrumenten daarvoor aanreikt.

3. Mensen geven aan dat de bejegening nogal eens te wensen overlaat, bijvoorbeeld als ze niet het door de zorgverlener gewenste gedrag vertonen.

In mijn proefschrift dat ging over de zorgverlening aan mensen die gaan sterven in de huisartspraktijk, heb ik als ideaal het participatiemodel genomen. 9 Dat model lijkt me ook voor de chronische zorg goed bruikbaar. Het participatiemodel veronderstelt een volwassen wijze van communiceren waarin de ander wordt uitgedaagd naar andere en nieuwe vormen van zorg te kijken en wordt aangesproken op de eigen verantwoordelijkheid. Van een dergelijke uitdagende en activerende communicatie is nog weinig sprake, ook omdat ons aanbod nog steeds traditioneel is. En als we willen veranderen, dan nemen we de ander niet mee. Dat gebeurde in de jaren zeventig, toen we van het verzwijgen van fatale diagnoses plotsklaps overgingen naar het vertellen van de hele waarheid, ook als mensen daaraan niet toe waren. En nu, als we van een pamperend aanbod plotseling overgaan op zelfmanagement sec vanuit het motief dat het ons beter uitkomt.

In het gesprek moeten we ook blijk geven van realisme over datgene wat we te bieden hebben. Niet alles is immers voorhanden. Wat we te bieden hebben moet ook passen in de kaders voor de beroepsuitoefening, zoals normen en waarden, eisen van effectiviteit, veiligheid en doelmatigheid, en gegevenheden als regelgeving en verzekeringstelsel.

Met het gesprek bedoel ik geen soft gedoe maar een open wederzijdse communicatie, waarbij een zorgverlener best mag proberen de patiënt te overtuigen, zolang het maar geen manipuleren of dreigen wordt. De techniek van motivational interviewing beoogt immers ook de patiënt te motiveren om het gedrag te veranderen. Uiteindelijk gaat het er echter om dat het zorgplan wordt gebaseerd op wat de patiënt echt wil. 
Over de ziekte-specifieke inhoud heb ik het vandaag niet, omdat deze per chronische ziekte verschilt. Voor de belangrijke chronische aandoeningen zijn in richtlijnen vervatte inhoudelijke normen voor verantwoorde zorg opgesteld, die zo mogelijk gebaseerd zijn op 'evidence'. Het feit dat hier sprake is van normen, maakt het mogelijk om van de traditionele individuele aanpak over te gaan naar een meer of minder collectieve aanpak. Meer of minder, omdat de aanpak moet zijn gebaseerd op de verfijnde diagnose en de competenties van patiënten. Dit is maatwerk. Maar als in de inkaarting zowel ziekteals persoonsgebonden factoren zijn meegenomen, kan vervolgens geprotocolleerd gebruik worden gemaakt van bestaande richtlijnen.

\section{Inhoud en organisatie}

De collectieve aanpak vormt de basis van disease management, een term waarvoor we in ons land wat allergisch zijn, maar die in feite inhoudt dat zorg voor mensen met een specifieke chronische ziekte gestructureerd plaatsvindt, dat de er echt toe doende parameters over proces en effecten worden gemeten en dat er inspanningen zijn om op basis daarvan de kwaliteit te verbeteren. ${ }^{10}$

Disease management wordt wel in twee betekenissen gebruikt: als aanduiding voor een zorgprogramma op het gebied van een specifieke aandoening en als een aanduiding voor een type zorgorganisatie. Als ik vandaag spreek over disease management, doel ik op een zorgprogramma dat aan de zojuist genoemde kenmerken voldoet.

Disease management gaat verder dan wat in Nederland wordt aangeduid als werken in zorgketens en netwerken. Zorgketens zijn van toepassing bij acute aandoeningen; bij chronische aandoeningen zijn netwerken van belang. Zo'n netwerk bestaat uit elementen die samenhang en structuur vertonen.

Vanwege die samenhang spreken we van geïntegreerde zorg. 


\section{Chronic Care Model}

Op het gebied van diabetes, COPD en vasculair risicomanagement zijn over het 'hoe' van de zorgverlening de afgelopen tijd zogeheten zorgstandaarden ontwikkeld waarvan er twee, die voor COPD ten dele en die voor vasculair risicomanagement, in hoge mate gebaseerd zijn op het Chronic Care Model dat Wagner in Seattle heeft ontwikkeld en dat door de Wereldgezondheidsorganisatie (WHO) is geadopteerd. ${ }^{112}$

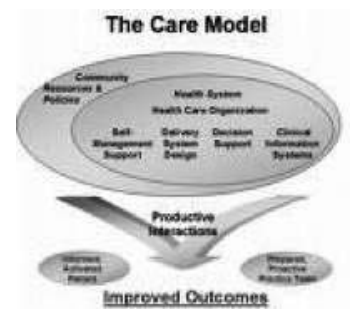

Het Chronic Care Model heeft als oogmerk de zorg te optimaliseren en doet dit door nadere invulling te geven aan de inhoudelijke, organisatorische en beleidmatige aspecten van zorgprogrammering. Het succes van dit model wordt afgemeten aan wat van professionals mag worden verwacht en dus aan hun bijdrage aan het optimaliseren van de klinische en functionele uitkomsten, iets dat ik straks enigszins zal relativeren.

Voor dat succes is een productieve interactie tussen enerzijds de patiënt en anderzijds degenen die zorg verlenen, hier het praktijkteam genoemd, essentieel. Het doel hiervan is de patiënt - waar dit mogelijk en verantwoord is - zoveel mogelijk zelf bij de behandeling te betrekken en daarvoor ondersteuning te bieden.

Van dit team fungeert één persoon als centrale, eerst aanspreekbare en coördinerende zorgverlener, die de patiënt in zijn zelfmanagement ondersteunt en naar de verdere zorgverlening toe als een frontoffice functioneert. Zonodig kan de centrale zorgverlener een beroep doen op een functioneel samenwerkend netwerk als backoffice met competente professionals met een heldere taakafbakening.

Het praktijkteam zelf kan weer onderdeel vormen van een groter geheel met gelijke teams of organisaties als het ziekenhuis en de GGD. Het netwerk is geen los verband, maar beschikt over een stevige inhoudelijke en organisatorische aansturing, in mijn ogen steviger dan bij veel zogeheten zorggroepen thans het geval is. De taak van de 
leiding is ervoor te zorgen dat de professionals hun werk goed kunnen doen en dat de organisatie goed functioneert. Zij is verantwoordelijk voor de aanwezigheid en het gebruik van protocollen en zorgplannen, voor de taakdeling aan en de opleiding van beroepsbeoefenaren, voor de beschikbaarheid van informatiesystemen ten behoeve van het elektronische patiëntendossier, beslissingsondersteuning, monitoring en benchmarking. Zij onderhandelt met de verzekeraars over prijs en kwaliteit. Daarnaast wordt er in het Chronic Care Model rekening mee gehouden dat zorgverleners en zorgorganisaties afhankelijk zijn van de vigerende regelgeving en financieringsystemen.

\section{Integratie van medische en gedragsgerichte zorg}

Ik laat $U$ het resultaat zien van diabeteszorg met behulp van een structurerend informatiesysteem bij huisartsen.13

Vóór de invoering van het informatiesysteem was de kwaliteit die de 15.260 geïncludeerde patiënten met diabetes type 2 kregen, ronduit slecht. Een aantal volgens de richtlijn uit te voeren verrichtingen werd niet uitgevoerd en te veel patiënten hadden een voor verbetering vatbare levenswijze.

Tabel 2: Kwaliteitsindicatoren bij toepassing van soft-ware van Diagnosis4Health/ Vital Health door huisartsen op To en na 1 ( $T_{1}$ ) en 2 jaar ( $T_{2}$ ) bij 15.260 patiënten met diabetes mellitus, type 2 (in percenten)

\begin{tabular}{|llll|}
\hline Indicato & T0 & T1 & T2 \\
\hline Rokers & & & \\
\hline Geen voetcontrole & 18 & 18 & 18 \\
\hline Geen funduscontrole & 38 & 24 & 16 \\
\hline $\mathrm{Hb}_{\text {AIC }}>7.0$ & 43 & 27 & 16 \\
\hline Tot Chol $>5.0$ & 46 & 39 & 27 \\
\hline Bloeddruk $(>150 ;>85)$ & 61 & 53 & 36 \\
\hline BMI $>27.0$ & 63 & 56 & 44 \\
\hline
\end{tabular}

$\mathrm{Na}$ een jaar waren de resultaten aanzienlijk verbeterd en na twee jaar nog meer (tabel 2). Althans... voor wat betreft de klassiek medische parameters: veel vaker werden de voeten en oogfundus op tijd gecontroleerd en voldeden de waarden van het cholesterolgehalte en de bloeddruk aan de norm. Het rookgedrag en het gewicht waren echter nauwelijks verbeterd. Dat komt - denk ik - omdat voor gedragsveranderingen heel andere dan medische interventies uit de 
kast moeten worden gehaald. Een kenmerk van die interventies is dat er veel moet worden geïnvesteerd in het gedrag van de patiënt zelf. Het Chronic Care Model nu beoogt integratie van medische en gedragsgerichte zorg.

Ik zei al dat veranderen van gedrag geen sinecure is om ziekten te voorkomen. Dat geldt ook als mensen door ziekte zijn getroffen. Ook dan is het nodig dat psychologische mechanismen hierbij worden gekend, begrepen en in praktijk gebracht. De laatste jaren zijn er mooie voorbeelden ontstaan van samenwerking op het gebied van gezondheidsbevordering tussen GGD, GVO en klinische vakgroepen, inclusief de huisartsgeneeskunde.

\section{Activering van de patiënt}

Het Chronic Care Model is gebouwd op het inzicht dat gedragsverandering niet lukt zonder de patiënt hierbij zelf de leidende rol te geven. Deze versterking van de rol van de patiënt zelf wordt wel aangeduid met patiënt empowerment. Op het gebied van diabetes laat onderzoek zien dat zelfmonitoring en een actievere rol van de patiënt op populatieniveau leiden tot een statistisch en klinisch relevante daling van het glucosegehalte en dat stapsgewijze leefstijlinterventies door een diëtist of diabetesverpleegkundige bij diabetespatiënten met hoog risico op complicaties resulteren in de gewenste verandering en betere glucose-instellingen. ${ }^{14}$ De literatuur over zelfmanagement laat zien, dat het bevorderen daarvan effectiever is dan veel gebruikelijke interventies, mits op een verstandige wijze en bij de juiste groep toegepast. ${ }^{15}$

Focus op zelfmanagement is geen idealistische prietpraat. Gedurende de 8.766 uren die een jaar telt, zijn mensen van wie de behandelaar keurig de NHG-richtlijn volgt immers in de regel zo'n 8.764 uur - 2 uur minder - op zichzelf aangewezen.

Ik pleit niet voor zelfmanagement zonder meer. Er moet immers wel goed worden opgelet wat mensen aankunnen, willen en weten; met andere woorden wat hun zelfmanagementvermogen of self-efficacy is. Daarom spreek ik liever over 'ondersteuning van zelfmanagement' waarbij behoort voorlichten over de aard van de ziekte, de symptomen en verschijnselen, wat normaal is en wat abnormaal, wat de werking van medicijnen is en hoe deze moeten worden gebruikt.

Maar mensen moeten daarvoor ook weten waarom bepaalde zaken worden geadviseerd, welke technologie er voorhanden is om met de beperkingen om te gaan, hoe men zelf kan bijhouden hoe het gaat, waar 
en hoe verdere informatie kan worden verkregen, wat er moet gebeuren en wie men kan bereiken als zich iets verontrustends voordoet. Deze informatie wordt vanzelfsprekend interactief verstrekt. In Maastricht hebben we daarvoor het Diabetes Interactief Educatie Programma (DIEP) ontwikkeld. ${ }^{16}$

Een dergelijke ondersteuning vergt een procesmatige benadering die in het begin tijd kost en later onderhoud vergt.

Op dit moment zijn zowel de praktijk als de financiering hier nog te weinig op ingesteld. Echter, als een dergelijke ondersteuning serieus wordt genomen, kan ze ertoe bijdragen dat mensen zelf eigenaar van hun ziekte worden en minder een beroep op de zorg doen. Als dat is bereikt, is er evenmin sprake meer van compliance, het mee-plooien met datgene wat de dokter voorschrijft, maar van gedrag gebaseerd op kennis en eigen keuzen.

Als $U$ me hierin volgt, moet $U$ ook de consequentie accepteren, namelijk dat we dan, op individueel niveau, niet altijd voor het klinisch maximaal haalbare gaan. Het is aannemelijk dat een aantal mensen keuzes maken op grond van andere overwegingen dan wij medici dat doen en aan hun invulling van levenskwaliteit grotere waarde hechten dan aan levensduur.

Als werkers in de gezondheidszorg in staat zijn hun rol te relativeren en te beschouwen als ondersteuning en niet als overname van alle verantwoordelijkheden voor de ander, is het ook vanzelfsprekend dat de chronische patiënt - als hij of zij dat wenst - zelf drager wordt van zijn informatie zoals vastgelegd in het EPD en dat www.mychronicdisease. org werkelijkheid wordt.

\section{Het zorgaanbod}

Ik ga nu terug naar het aanbod om patiëntgerichte zorg te realiseren. Een probleem hierbij zijn opvattingen over domeinen en weerstanden om functioneel te denken en niet hiërarchisch. Om hierin verandering te brengen hebben wij hier in Maastricht in een situatie met een beleidsimpasse een verleidingsstrategie toegepast. In 1994 werd meer dan de helft van de patiënten met diabetes hier in het ziekenhuis behandeld, nu is dit $20 \%$. Destijds maakte de financiering via een aanneemsom voor alle zorg tezamen, de zogeheten lump sum, de zorgverlening aan zoveel patiënten in toenemende mate onaantrekkelijk voor het ziekenhuis. De huisartsen werden in die tijd 
voor hun ziekenfondsdeel betaald met een vast bedrag per patiënt per jaar, de abonnementsprijs. Niet geheel ten onrechte, vreesden zij dat het ziekenhuis de chronische patiënt over de muur zou kieperen en dat zij geacht zouden worden die patiënten in het vervolg te behandelen zonder daarvoor financieel gecompenseerd te worden.

Via een aantal potjes - waaronder de beruchte U-bocht van de AWBZfinanciering - lukte het ons geld te verkrijgen voor een experiment. We begonnen met de in het ziekenhuis behandelde diabetespatiënten van tien huisartsen die voldeden aan bepaalde criteria. Deze konden in de praktijk van hun huisarts op basis van gedetailleerde protocollen worden behandeld door diabetesverpleegkundigen uit het ziekenhuis. Hiermee werd een combinatie van horizontale en verticale substitutie gerealiseerd. De coördinatie werd geregeld vanuit het Transmuraal en Diagnostisch Centrum. De Inspectie voor de Gezondheidszorg informeerden we 'en detail' en deze gaf ons schriftelijk toestemming.

Vanwege dit experimentele karakter werd hieraan een robuuste evaluatie gekoppeld, die geresulteerd heeft in twee promoties..$^{178}$

Het experiment werd een geweldig succes. De huisartsen ervoeren de grotere deskundigheid van de verpleegkundigen en wilden deze ook inschakelen voor hun niet of nog niet verwezen patiënten. De diabetesverpleegkundigen vroegen al snel om uitbreiding van hun opleiding naar vaatziekten omdat ze daar leemtes ervoeren. Alleen met de stellige belofte dat ze bij succes ook een verpleegkundige zouden krijgen, konden we de controlepraktijken ertoe bewegen hun deelname te continueren. Na de diabetes volgde al snel COPD. Rond de eeuwwisseling stond vast dat de wijze waarop wij de verpleegkundigen inzetten verantwoord was en door de patiënten in hoge mate werd geapprecieerd.

Het succes stelde ons in staat om het experiment om te zetten in zorgprogramma's op het gebied van diabetes en COPD. Bij zowel Matador, het diabetesprogramma, als bij het COPD-programma waren al snel de patiënten van zo'n 60 huisartsen betrokken. Als de patiënt daarmee instemde, bepaalde een kernteam van medisch specialist, gespecialiseerde verpleegkundige en huisarts op grond van de complexiteit van de aandoening door wie de patiënt zou worden behandeld. Met andere woorden: de toewijzing geschiedde op basis van stratificatie. Een minderheid kreeg nog zorg van een specialist maar het merendeel werd in de huisartspraktijk behandeld waar de patiënten met een wat complexere ziektesituatie werden gezien door de gespecialiseerde verpleegkundige en de patiënten zonder complicaties 
door de huisarts.

Lotte Steuten heeft in haar proefschrift aangetoond dat met deze werkwijze kwaliteitswinst en soms ook financieel voordeel is behaald. Dit is geheel toe te schrijven aan de gespecialiseerde verpleegkundigen die bij mensen in een complexere situatie waren ingezet. ${ }^{19}$ We schrijven dit toe aan de gestructureerde en geprotocolleerde aanpak van de verpleegkundigen, waardoor onder meer het aantal onnodige opnames wordtgereduceerd.OokinWest-Frieslandwerd meteen programmatische aanpak een scherpe daling van het bloedglucosegehalte en maten voor vasculair risico waargenomen.

Men zou hopen dat de aanwezigheid van de gespecialiseerde verpleegkundige ook invloed zou hebben op de zorg door de huisarts, maar daarin hebben we geen veranderingen kunnen waarnemen. Daarvoor is een fundamentele verandering van de werkwijze richting Chronic Care Model noodzakelijk. In die richting gaat al het Quattromodel, dat beoogt de samenwerking tussen medisch specialist, huisarts, gespecialiseerde verpleegkundige en praktijkondersteuner functioneel te structureren. Maar om deze vier categorieën beter te positioneren binnen het Chronic Care Model, zijn er krachtigere stuuren bijstuurmechanismen nodig. Het recente artikel van Legemaate laat zien dat dit tevens aanpassing van een aantal juridische regelingen, zoals de BIG, vergt. ${ }^{20}$

\section{De overgangssituatie}

Laten we nu eens kijken waar we op dit moment staan. In hoeverre gaan de nu van de grond komende zorggroepen passen in het geschetste ideaal van zorgverlening? Zorggroepen zijn organisatorische en juridische entiteiten die de verantwoordelijkheid voor de zorgverlening op het gebied van één of meerdere chronische ziekten of zorgproblemen op zich nemen. De zorggroepen gaan nu bijna uitsluitend over diabeteszorg maar al dit jaar komt daar de COPD-zorg bij. Te verwachten is dat de aandacht zal worden uitgebreid tot meer chronische ziekten. Op dit moment hebben de huisartsen binnen de zorggroepen een prominente positie. Vrijwel overal bestaan deze groepen niet alleen uit huisartsen met bijzondere interesse in het onderwerp van zorg, maar uit alle huisartsen die binnen een regio werkzaam zijn. De zorggroep sluit via een soort diagnose-behandel-combinatie (DBC) als aannemer een contract af met de zorgverzekeraar over de prijs, het te leveren zorgprogramma en de verantwoording van de nakoming 
ervan. Soms gebeurt dit modulair op grond van zorgprofielen of extra verrichtingen. De zorggroep betaalt de kosten verbonden aan de eigen organisatie, de werkzaamheden van haar leden en de declaraties van haar onderaannemers, zoals het laboratorium, de medisch specialist, de paramedici en eventueel de geneesmiddelenvoorziening. Zorggroepen worden gezien als organisaties voor disease management. Het ontstaan van zorggroepen heeft ongetwijfeld een nieuwe dynamiek in het huisartsenland doen ontstaan. Ik ken uitstekende zorggroepen met uiterst gemotiveerde huisartsen en beschouw deze ontwikkeling dan ook als positief, maat plaats daarbij wel een aantal kanttekeningen en doe enkele suggesties.

a. De zorggroep als vereniging van regionale huisartsen

Traditioneel gaan artsen collegiaal met elkaar om en hebben ze al gauw de neiging elkaar niet af te vallen, zelfs als er sprake is van disfunctioneren. Hoe zal dit gaan nu zowel belangen van de individuele leden als die van de groep als geheel in het geding zijn? Een belangrijke test lijkt me of zorggroepen in staat zijn disfunctionerende collegae te corrigeren of zelfs uit de zorggroep te verwijderen als dat nodig is. Dit lukt alleen als besturing en leiderschap goed functioneren.

b. Door elkaar lopende rollen van de huisarts

Een ander aandachtspunt is dat huisartsen als gevolg van deze insteek nu drie rollen in de organisatie vervullen:

1. ze zijn medeverantwoordelijke voor de zorginhoudelijke vormgeving van de zorg en dragen daaraan persoonlijk bij;

2. ze zijn toeleverancier aan het netwerk voor zorg die ze zelf niet kunnen leveren, zoals aan de medische specialist bij complexiteit en aan de diëtist bij voedingsproblemen;

3. ze zijn financieel deelgenoot in het succes van de organisatie bij het realiseren van haar doelstellingen en onderscheiden zich hierin van de andere professionals binnen het praktijkteam.

Als de prijsafspraak grofmazig is, kan het financieel verleidelijk worden om zo weinig mogelijk te verwijzen en zo laag mogelijk gekwalificeerde anderen in te schakelen. Het is goed dat zorgverleners worden gestimuleerd zo goedkoop mogelijk te werken, maar het wordt een risico als de kwaliteit hieronder lijdt.

De vraag is ook of zo'n overheersende positie wel past binnen een praktijkteam, gebaseerd op samenwerking van gelijkwaardige professionals en hoe deze ontwikkeling zich verhoudt tot de beoogde marktwerking. Is het wel wenselijk dat alle zorg door één regionaal kartel wordt aangeboden? Krijgt zo' $n$ kartel bedoeld of onbedoeld geen 
te machtige positie en valt er voor de patiënten nog wel wat te kiezen?

Hoewel ik erken dat deze bevoordeelde positie van de huisarts historisch geworteld is en politiek nodig is geweest om het verzet van de huisartsen tegen de zorgverzekeringswet te beëindigen, ben ik er niet voor om binnen een regio één organisatie en één beroepsgroep een exclusieve positie te geven.

c. De positie van generalist en specialist

Huisartsen zijn generalisten; in de chronische zorg is er tevens een rol voor specialisten weggelegd. Met de komst van de zorggroepen neemt de rol van de huisarts toe. Dat is een opvallend fenomeen in een periode van toenemende specialisatie. Van complexe aandoeningen, zoals kanker, staat vast dat specialistische behandeling, zelfs binnen de te onderscheiden orgaanspecialismen, zinvol is. Die zinvolheid neemt toe naarmate de aandoening zeldzamer is.

Bij de chronische ziekten gaat het over aandoeningen waarvan de gemiddelde huisarts er toch zeker 50 in zijn praktijk heeft. Echter, de behandeling is op dit moment nog lang niet altijd optimaal. Mogelijk hangt dit samen met de mate van complexiteit en het samengaan van chronische aandoeningen met andere aandoeningen. Een op zich juiste behandeling van de ene aandoening is dan niet zelden nadelig voor de andere, maar dat zal juist ook bij specialisten spelen.

Recent hebben Van Bussel c.s. bij 300 patiënten uit Matador de bijkomende morbiditeit van mensen boven de 60 jaar geanalyseerd. ${ }^{21}$ Het merendeel van de bijkomende aandoeningen was gerelateerd aan diabetes, dus wat we tegenwoordig co-morbiditeit noemen, maar gemiddeld hadden deze patiënten ook hiervan twee los staande aandoeningen. De hoeveelheid aan diabetes gerelateerde co-morbiditeit, zoals cardiovasculaire aandoeningen, oogproblemen of nierproblemen, bleek een relatie te hebben met de mate van complexiteit dan wel de categorie behandelaar. De niet met diabetes te maken hebbende morbiditeit kwam echter evenveel voor, of de patiënt nu binnen Matador door de medische specialist, de gespecialiseerde verpleegkundige of de huisarts werd behandeld. Dit betekent niet dat we de gedachte van zorgprogrammering van een ziektespecifieke aanpak moeten laten vallen, maar wel dat we voor mensen die ook een ernstige andere chronische aandoening hebben en die, laat ik eens arbitrair zeggen, ouder zijn dan 75 jaar, een generalistisch model toe moeten passen waarin de huisarts en de geriater een centrale rol spelen.

d. De(huis) arts ten opzichte van de verpleegkundige

We zagen dat een groot aantal patiënten met een chronische 
aandoening verantwoord door een verpleegkundige kan worden geholpen. Sterke punten van verpleegkundigen zijn hun communicatievaardigheden, hun veelal gewonere sociale positie en hun vermogen om geprotocolleerd te werken. Dat artsen in het laatste minder goed zijn is niet zo vreemd, want van mensen die universitair zijn opgeleid, mag worden verwacht dat ze proberen te falsificeren en juist niet geprotocolleerd te werken. Dit alles betekent wel dat we scherper moeten bepalen wanneer we artsen en wanneer we HBO-geschoolden inschakelen. Huisartsen en medisch specialisten moeten zich naar mijn opvatting toeleggen op diagnostiek en situaties die zo complex zijn dat er niet of niet meer protocollair gewerkt kan worden.

e. De gespecialiseerde verpleegkundigen ten opzichte van de praktijkondersteuners

In zorggroepen fungeert de praktijkondersteuner ( $\mathrm{POH}$-er) nogal eens als eerst aanspreekbare voor mensen met een niet gecompliceerde chronische aandoening. Zijn domein bestrijkt in principe meer dan één aandoening. Dat is logisch vanwege de breedte van de problemen binnen een huisartspraktijk, maar strookt minder met ons vermoeden dat juist hun gespecialiseerde kennis een belangrijke bijdrage heeft geleverd aan het succes van de gespecialiseerde verpleegkundigen in de eerdere programma's. Daarbij worden $\mathrm{POH}$-ers ook korter opgeleid. Is het nu wel verstandig om zowel lagere eisen te stellen aan het opleidingsniveau als aan de breedte van het taakgebied? Ik begrijp wel dat de keus hiervoor voortkomt uit praktische omstandigheden om in een praktijk niet te veel verschillende zorgverleners te laten rondlopen, maar als ik rondkijk meen ik te kunnen zien dat deze halfhartigheid de kwaliteit niet ten goede komt. Mijn suggestie is de problemen anders op te lossen, bijvoorbeeld door gespecialiseerde verpleegkundigen een superviserende rol te geven naar de praktijkondersteuners.

\section{g. De grootte van de praktijk}

Als de huisarts met zo veel mensen moet samenwerken, waarvan een behoorlijk aantal face-to-face en de huisarts niet vanzelfsprekend de primus inter pares is, zal aan schaalvergroting niet ontkomen te zijn. Zelfs veel groepspraktijken en gezondheidscentra zijn te klein. Schaalvergroting heeft als verder voordeel dat het differentiatie binnen het generalisme mogelijk maakt en dat een gelijkwaardigere positie ten opzichte van het ziekenhuis of een gespecialiseerd centrum kan worden gecreëerd.

Schaalvergroting vereist een kapitaalinjectie. Al snel wordt hiervoor naar de verzekeraar gekeken maar ik weet niet of dit vanuit het oogpunt 
van counter vailing partyship verstandig is. Mijn voorkeur zou uitgaan naar een particuliere partij of een ziekenhuis.

h. Ziekenhuis, gespecialiseerd centrum en eerste lijn

In het algemeen is het om allerlei redenen niet gunstig voor mensen met een chronische aandoening om in een ziekenhuisomgeving te worden behandeld. Net werd echter ook gesuggereerd dat chronische zieken mogelijk baat hebben bij een ziektespecifieke benadering. Hoe valt dit te rijmen? De echelonnering van de jaren zestig en zeventig heeft gemaakt dat ziektespecifiek samenvalt met specialistisch en specialistisch met een ziekenhuisomgeving. Als we dit laatste niet willen, staan er bij een programmatische aanpak twee wegen open: behandeling in een perifeer gespecialiseerd centrum, zoals een diabetesof longcentrum, of in een generalistische omgeving. Het perifere centrum heeft de specialisatie als voordeel maar als nadeel dat het te gemakkelijk eigenstandig en niet in de gehele zorg geïntegreerd gaat opereren. Een aantal patiënten zal niettemin voorkeur hebben voor een gespecialiseerd centrum en een dergelijk centrum kan ook functioneren als tweedelijnsvoorziening voor huisartspraktijken. Mijn voorkeur gaat er naar uit dat huisartsen hun generalistische invalshoek integreren met een ziektespecifieke benadering.

\section{Samenhang tussen zorgstandaarden}

Disease management gaat over ziektespecifieke zorgprogramma's. Die kunnen in principe onafhankelijk van elkaar worden aangeboden. Ik denk echter niet dat een strikt gescheiden aanbod van specifieke programma's verstandig is. Een sterk punt van de vorming van de zorggroepen met een prominente rol van huisartsen is dat er daardoor voor een natuurlijk verband tussen de diverse ziektespecifieke benaderingen wordt gezorgd. Het kan worden verbeeld als een bloem waarvan het hart wordt gevormd door het Chronic Care Model als hét verbindende raamwerk van waaruit de ziektespecifieke benaderingen als bladeren uitwaaien. Bij het inrichten van die uitwaaieringen behoren patiëntenorganisaties, medisch specialisten en gespecialiseerde verpleegkundigen betrokken te zijn. ${ }^{22}$

Dit heeft consequenties voor de zorgstandaarden waarover ik eerder sprak. Deze geven voor de betreffende zorgcategorie een nadere specificatie van de wijze waarop aan de in richtlijnen vastgelegde inhoud qua attitude en organisatie vorm kan worden gegeven. Het zou goed zijn als initiatiefnemers en de hierbij betrokken relevante organisaties het eens worden over het verbindende raamwerk. 


\section{Randvoorwaarden voor succesvolle implementatie Chronic Care Model}

Een paar opmerkingen over de programma overstijgende randvoorwaarden.

a. Ontwikkeling en onderzoek

Ook als het Chronic Care Model als raamwerk wordt geaccepteerd, is daarbinnen nog veel variatie mogelijk. Het is goed om daarmee ervaring op te doen en voor goed evaluatieonderzoek zorg te dragen. Willen we hiervan leren, dan zal de ervaring moeten worden gebundeld. In ons land is ZonMw hiervoor de geëigende organisatie. Het stimuleringsprogramma Diabetes Ketenzorg, het pas gestarte programma Disease Management Chronische Ziekten en het komende Innovatieprogramma voor Zorg en Preventie bieden hiertoe de gelegenheid. Daarnaast is het goed om breder te kijken wat de invloed is van nationale regelingen op de effectiviteit en doelmatigheid van de chronische zorg. Daarom doet het me ook plezier dat wij vanuit Maastricht zeer waarschijnlijk kunnen participeren in een consortium dat, gefinancierd door het $7 e$ kaderprogramma van de Europese Unie, de ontwikkelingen in Europa zal volgen.

Aan experimenten en evaluatie-onderzoek in dit complexe en snel veranderendezorgveld kleven aanzienlijke praktischeen methodologische problemen. Zo zijn er op dit moment nauwelijks stabiele controlegroepen te vinden en kunnen interventies niet strak en geordend worden ingevoerd. Nog ingewikkelder wordt het als we de uitkomsten willen relateren aan de opvattingen die patiënten zelf hebben over de zorg die ze willen krijgen. Deze problemen maken dat de methodologie op zich al een interessant object van studie vormt.

\section{b. Opleiding}

Chronische zorg stelt nieuwe eisen aan de professionals. Ik noemde al de positie van de huisartsen. Als, wat ik hoop, huisartsen complexere co-morbiditeit en multimorbiditeit als hun kerntaak zien en als het tot differentiatie komt, dan moet hun klinische competentie worden opgekrikt en dat heeft consequenties voor de opleiding, het registratiesysteem en de rol van medische specialisten daarbij. Hetzelfde geldt voor de gespecialiseerde verpleegkundigen die in de praktijk als intermediair tussen de huisartsen en de medisch specialisten en tussen in- en extramuraal fungeren. Ik hoop ook dat er aan onze instelling een op deze groep gerichte masteropleiding zal komen, iets waarmee de NVAO al in 2004 heeft ingestemd, maar waarvan het om politieke redenen nog niet is gekomen.

\section{c. Financiering}

Tenslotte vraag ik aandacht voor de financiering van disease 
management. Het is niet goed als allerlei financieringssystemen, zoals abonnement, verrichtingentarief, DBC voor financiering van de ziektespecifieke zorg en straks mogelijk collectieve preventie door elkaar lopen. Dit is mogelijk in een beginsituatie niet te vermijden, maar als we het Chronic Care Model met succes van de grond willen tillen, dan zal er in de financieringssystematiek, de vermogenspositie van de organisatie en de beleidsregels voor chronische zorg nog heel wat moeten veranderen. Kortom, voldoende werk aan de winkel voor een volgende generatie.

\section{Dankwoord}

Mijnheer de rector magnificus, dames en heren,

Ik heb genoeg gezegd over de chronische zorg die mij voor ogen staat en kom daarmee toe aan het nemen van afscheid als hoogleraar aan deze universiteit.

Het College van Bestuur en het bestuur van het Universitair Medisch Centrum Maastricht dank ik zeer voor de gelegenheid die ik heb gehad om van datgene wat mij aan het hart gaat, de zorg voor chronische zieken, mijn werk te mogen maken. $\mathrm{lk}$ heb me in al deze jaren door $U$ gesteund gevoeld.

Hetzelfde geldt voor iedereen met wie ik heb mogen samenwerken. Het is me onmogelijk om hier namen te gaan noemen want dan zou ik ongetwijfeld iemand onbedoeld overslaan en zoiets wil ik op deze heugelijke dag niet op mijn geweten hebben. Wel wil ik een aantal categorieën noemen. In het bijzonder wil ik iedereen bedanken met wie ik in de pioniersfase hier de innovatieprojecten heb kunnen opzetten, niet alleen op het gebied van de chronische zorg maar vooral in het begin ook op dat van de palliatieve zorg. Ik noem de coördinatoren, de verpleegkundigen, de medisch specialisten en de huisartsen die - ondanks de kritiek die er soms ook was - medewerkten aan ons experiment. Ik doel op ook degenen die betrokken zijn geweest bij de wetenschappelijke evaluatie, van adviseur en promovendus tot onderzoeksassistent.

Veel dank ben ik ook schuldig aan landelijke organisaties die ons in deze tijd hebben gesteund, de toenmalige NCCZ, SGO, ZonMw, het ministerie van VWS, de verzekeraars CZ en VGZ en het IKL. Belangrijk voor mij was ook de steun van allen die destijds betrokken waren bij de vakgroep Zorgwetenschappen. 
Toen ik decaan van de Faculteit Gezondheidswetenschappen was, kreeg ik steun van anderen. Bij deze gelegenheid spreek ik mijn dank uit aan alle medewerkers indertijd van het bureau van de faculteit en de universiteit. Dat geldt ook voor de collega-hoogleraren en iedereen die er misschien wel eens last van heeft gehad dat ik voor de troepen uit liep of - op het moment suprème - trouw bleef aan voor mij belangrijke principes en uitgangspunten.

$\mathrm{Na}$ het decanaat is er een periode gekomen waarin het inhoudelijke werk weer moest worden opgepakt en dat gaat niet zonder moeite. Veel steun heb ik ondervonden van onze kleine, maar wel productieve onderzoeksgroep en van de directie van Caphri.

Nieuwe uitdagingen deden zich voor, zoals de vorming van de vakgroep Sociale Geneeskunde vorig jaar. Ik heb niet lang jullie voorzitter kunnen zijn maar ik reken erop dat de nieuwe hoogleraar jullie groep tot een hecht team zal smeden. Het succes van de vakgroep is belangrijk voor de Academische Werkplaats Publieke Gezondheid Limburg die twee jaar geleden van de grond is gekomen dank zij hechte samenwerking met de GGD, de voorzitter van de vakgroep GVO en anderen die de ideeën daarvoor hebben aangereikt.

In december 2005 werd ik ook verantwoordelijk voor het reilen en zeilen van het iRv te Hoensbroek waarvan de UM één van de drie founding fathers was. Onmiddellijk na mijn aantreden bleek een zeer ingrijpende reorganisatie onvermijdelijk te zijn. Ik heb grote waardering voor de spankracht van alle betrokkenen waardoor dit is gelukt zonder schade aan te brengen aan de persoonlijke verhoudingen. Op 1 juli 2007 is het iRv opgegaan in Vilans waarvan ik sindsdien deel heb uitgemaakt van de Raad van Bestuur. Mijn bijdrage zag ik als het goed positioneren van de locatie Hoensbroek en het innoveren van heel Vilans. Ik dank mijn beide collegae voor het vertrouwen en het secretariaat en de overige medewerkers voor alle hulp die ik van ze heb mogen ontvangen.

In mijn dank betrek ik uitdrukkelijk ook al degenen die mij persoonlijk nabij staan en me - weliswaar niet in alle gevallen zonder discussie - de ruimte hebben gegeven om tijd te besteden aan datgene wat ik nodig achtte.

Mijnheer de rector, dames en heren:

Ik heb gezegd. 


\section{Literatuur}

1 Groffen W. Subdisciplinaire verstandhoudingen. Hulpverlenen en Veranderen (1975), afl. 1: 1-19.

2 Landelijke Huisartsen Vereniging. Concept-rapport basis-takenpakket van de huisarts. Utrecht: LHV, 1982.

3 KNMG. Standpunt inzake euthanasie. Medisch Contact (1984); 39: 990-8.

4 Staatssecretaris van Welzijn, Volksgezondheid en Cultuur. ChronischZiekenbeleid; chronische patiënten niet buitenspel. Brief aan de Tweede Kamer, vergaderjaar 1990-1991, kamerstuk 22025.5

5 Spreeuwenberg C. (Net) werken voor chronisch zieken. Oratie. Maastricht: Rijksuniversiteit Limburg, 1994.

6 Nationaal Kompas versie 3.1317 april 2008, RIVM: www.rivm.nl.nationaalkompas.

7 Meeteren-Schram MT van, Baan CA. Diabetes en depressie; een zorgelijke combinatie. Bilthoven: RiVM, 2007.

8 Groffen W. Subdisciplinaire verstandhoudingen. Hulpverlenen en Veranderen (1975), afl. 1: 1-19.

8 Landelijke Huisartsen Vereniging. Concept-rapport basis-takenpakket van de huisarts. Utrecht: LHV, 1982.

8 KNMG. Standpunt inzake euthanasie. Medisch Contact (1984); 39: 990-8.

8 Staatssecretaris van Welzijn, Volksgezondheid en Cultuur. ChronischZiekenbeleid; chronische patiënten niet buitenspel. Brief aan de Tweede Kamer, vergaderjaar 1990-1991, Kalsbeek C. Wat wil de patiënt? Picasso magazine, maart 2008 (11): 7.

9 Spreeuwenberg C. Huisarts en stervenshulp. [Proefschrift R.U.Utrecht]. Deventer: Van Loghum Slaterus, 1981.

10 Spreeuwenberg C. Ten characteristics for an ideal disease management programme. In: Schrijvers G, Spreeuwenberg C, Laag H van der, Rutten G, Naborro G, Schene A, Linden Barbara van der, Acampo M. Disease Management in the Dutch Context. Utrecht; Igitur, 2004.

11 Wagner EH, Austin BT, Davis C, Hindmarsch N, Schaefer J, Bonomi A. Improving Chronic Illness Care: translating evidence into action. Health Affairs (2001), 20 (6): 64-78.

12 Bodenheimer T, Wagner EH, Grumbach K. Improving Primary Care for Patients with Chronic Illness. JAMA (2002), 288 (14): 1775-9

13 Deze gegevens zijn me vriendelijk ter beschikking gesteld door Dr. R. de Neeter van Diagnosis4Health/Vital Health

14 Welschen LMC. Disease Management for Patients with Type 2 Diabetes: towards Patient Empowerment. Academisch Proefschrift, Vrije Universiteit Amsterdam, 2008.

15 WHO Europe. How can chronic disease management (programmes) operate across care setting and providers? Health Evidence Network/European Observatory Systems and Policies: Policy Brief Series, 2008.

16 Zie: www.diep.info 
17 Vrijhoef HJM. Is it justifiable to treat chronic patients by nurse specialists? Evaluation of effects on quality of care. Thesis. Maastricht University; Maastricht, 2002.

18 Eijkelberg IMJG. Key factors of change processes in shared care. Viewpoints of managers, care providers and patients. Thesis. Maastricht University, 2007.

19 Steuten LMG. Evaluation of disease management programmes for chronically ill. Thesis. Maastricht University, 2006.

20 Legemaate J. Ondersteuning in de huisartspraktijk: juridische aspecten. Ned Tijdschr Geneeskd (2008); 152: 1309-12.

21 Bussel B van, Ferreira I, Castermans P, Nieuwenhuijzen Kruseman A. Polymorbidity in diabetes in older people: consequences for care and vocational training. Postgrad Med J 2007; 83: 763-7.

22 Last I. Patiëntenorganisaties en zorgstandaards. Afstudeerscriptie. Nijfer en Universiteit Twente, 2006. 
